\title{
Unique Hennebique Bridges in Lublin, Poland
}

\author{
Slawomir Karas* \\ Road and Bridge Chair, Lublin University of Technology (LUT), Poland \\ *Corresponding author: s.karas@pollub.pl
}

Received January 26, 2013; Revised April 05, 2013; Accepted April 07, 2013

\begin{abstract}
Seeking the origins of the reinforced concrete (RC) technology, one certainly meets the name of François Hennebique. His genius and powerful organisation, known as Le Béton Armé Systéme Hennebique, were crusial for developing RC in theory and practice. And it is bridges that played a significant role in his activity. Nowadays, the city of Lublin, Poland, may pride itself on two bridges in Hennebique technology, the heritage of those great days. The following is a concise account of the successful restoration of one of the two bridges but also a presentation of the other one being in great need of renovation. The bridges mentioned above were constructed by the Polish engineer Marian Lutosławski, who highly deserves being treated as a RC pioneer. The structure of Lublin's bridges was thoroughly examined in many aspects, especially by applying a FEM analysis, non-destructive methods and a testing compressive strength on the cores taken. The carrying load capacity was estimated in accordance with the Polish standards and Eurocodes. As a result of the restoration there appeared a possibility of formulating a thesis on the concept of the RC beam Hennebique bridges as a modified form of beam wooden ones. The arguments which definitely prove the thesis have been formulated. Both of the bridges mentioned above constitute a significant contribution to the world's RC technical heritage.
\end{abstract}

Keywords: historic bridges, Hennebique, restoration, $R C$

\section{Introduction}

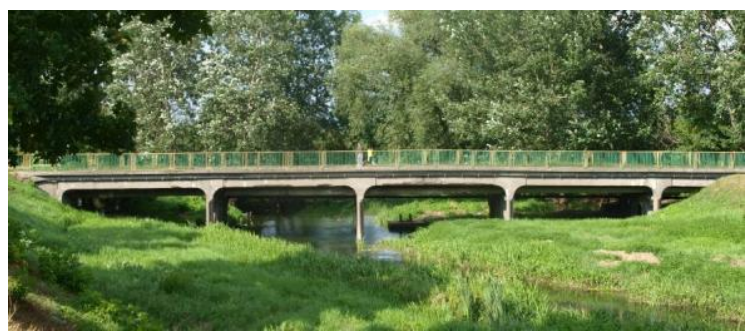

Figure 1. The bridge at Lublin's Kalinowszczyzna quarter built in 1908; the present view

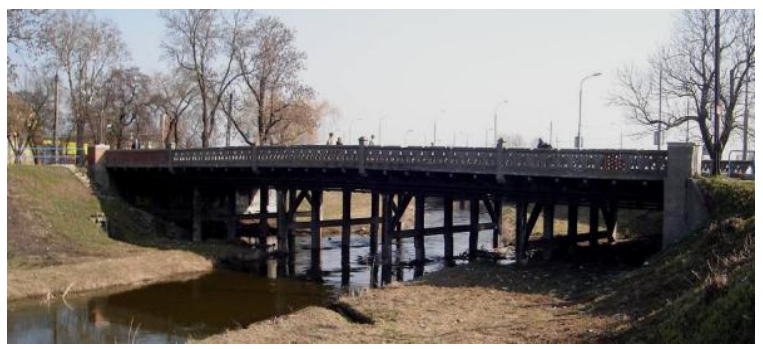

Figure 2. The other bridge in Lublin completed in 1909; the view of 2008

At the turn of 1908, see Figure 1, and 1909, Figure 2, there were constructed two bridges across the Bystrzyca River in the city of Lublin located in the east of Poland. Both were erected by the engineer Marian Lutosławski company, both were designed according to François Hennebique's technology. In those days the constructional method of reinforced concrete had already been well mastered, however still innovative and developing in a large number of technological and theoretical fields, the way it is perceived nowadays.

This paper is intended to be a summary of different aspects of the bridge technology mentioned above.

The city of Lublin was founded at the crossroads of the Lublin-Vilnius-Moscow and Lublin-Lvov-Kiev routes, both of which crossed the Bystrzyca River with fords or wooden bridges. Its hydrological and foundation conditions were known from everyday use, the position of river passages being practically unchanged. For hundreds of years the river could be forded in just two points. Hence there were some permanent or temporary wooden bridges built, the fact revealed by archaeological research. At the beginning of the 20th century the city's growth was increasingly rapid and territorially extensive, that is why some new streets and bridges were required to render the transport system efficient. The decision to build concrete bridges instead of the wooden ones was purely economical. In those days reinforced concrete was thought to be very durable which doesn't need repairs ${ }^{l}$. After the auction o open bids the suitable offer was submitted by the Lutosławski Technical Bureau. He was given 6 months to perform constructional work and managed to meet the dead line. In 1908 the bridge's capacity stood the proof tests carried out.

However, the bridge was rather peripheral, the quarter of Kalinowszczyzna being situated on the outskirts of the city. As well as that, it was a pure constructional structure without any ornaments, Figure 1. It was closed for motor

\footnotetext{
${ }^{1}$ Following the text from Ziemia Lubelska (The Land of Lublin County) journal issuing those days, 1909.
} 
cars in the 1970 s when the city traffic was moved to a new bridge, though it is still used by a nearby shopping centre customers as a footbridge.

The other bridge, Figure 2, was situated pretty close to the city centre, on the street connecting the railway station with the town hall, which highly emphasized its position. By the decision of The City Council the bridge structure was enriched by adding a, fashionable at the time, neogothic balustrade, which resulted in splendour proportionate to the position of the magistrate. The balustrade that should connect the baroque richness with gothic open-works like those of Saint-Séverin Church in Paris was suggested by architect Jan Heurich Jr. The final effect, gorgeous imperial impression, fulfilled the municipal officials' requirements. The bridge and its balustrade served the citizens for over a 100 years. The bridge has also got an informal name - the Old Bridge.

As a matter of fact the bridges introduced here constituted a typical repeatable project, in fragments adapted the local needs. In [4] there can be seen two similar bridges erected at those days in Russia.

Lublin's historical bridges are connected with many interesting personalities, two of them being most prominent. The first one it is Francois Hennebique, the world's pioneer of RC, while the other - the Polish engineer Marian Lutosławski. Their engineer activities are depicted in the section below.

\subsection{Marian Lutoslawski (1871-1918)}

Having graduated from Riga (1894) and Darmstadt (1896) Universities of Technology, he became an innovator in the fields of electricity and RC in Poland. An electric plant needing special buildings, he studied some $\mathrm{RC}$ technologies. RC means cement and reinforcement. At the time bar iron was available, however access to cement was thought to be a problem. As a result Lutosławski decided to organize his own production through building his own cement plant. He was the first to erect a concrete building in Warszawa and four RC bridges in the Hennebique technology, two of which, still existing, are the subject of the considerations.

Apart from his engineering activity, he was highly involved in educational project through writing technical articles or monographs and lecturing.

The heritage of M. Lutosławski's engineer practice is the two bridges in Lublin depicted here. Both of them could be characterized as constructed with an exceptional care of detail by means of using different concrete mixtures for different elements. The high quality of the works carried out might have been the reason why he was offered cooperation with F. Hennebique as his agent, the other relevant person while analysing the Lublin historic bridges.

\subsection{François Hennebique (1842-1921)}

This remarkable person has been examined in dozens of aspects and always seems to be more and more fascinating. His leading position [2], [7] in his days was achieved due to two elements of his professional activity: genius intuition resulting from a thorough knowledge on structures and on the array of RC applications, acquired through constructional practice, forming a net of selected contractors and agents.
F. Hennebique purchased the Monier patent on concrete reinforcement and developed it in many ways patenting his own concepts in many European countries, Britain included, as well as the USA, Asia and Africa, [3,8]. Taking these achievements into consideration, there are two patents that must be called crucial: 1 . the orthotropic bridge plate [1] and 2. the RC pile, known today as the Hennebique pile. In addition to his innovative work he built a company which spanned the globe. He introduced his solutions in the form of patents or even technical projects by means of the representative system Béton Armé (armoured concrete), the Hennebique term for RC. F. Hennebique's innovations and management activity as well as his well known technical magazine of the same title Le Béton Armé $e^{2}$ (LBA) became creative tools for his conquest of the world.

While France, Belgium [9], Italy and Switzerland were totally influenced by F. Hennebique a number of obstacles were spotted in Germany [6], some objection appearing. In the article [6] it reads that the licence fee was $\sim 10 \%$, which might have been considered too high by thrifty Germans. However, the Hennebique technology was not discriminated against in Germany and the number of Hennebique applications was similar to that in Russia or Austria, see [2].

All things considered, it is obvious while looking around that the world is in need of a person to follow F. Hennebique's genius.

\section{Lublin Historic Old Bridge}

The construction works on the Old Bridge were carried out for 6 months, despite the heavy winter with temperatures dropping to -20 degrees Celsius and spring flooding. During the proof load tests a steam roller of $160 \mathrm{kN}$ weight was used as the main static and movable load. After 1.5 hour of loading, the self-registering apparatus registered the maximum deflection value equal to $0.9 \mathrm{~cm}$, while the designed admissible one was $1.6 \mathrm{~cm}$. The bridge load rating was estimated at $1680 \mathrm{kNm}$, $336 \mathrm{kNm}$ per one girder as mean value. The last constructional works being completed on $17^{\text {th }}$ July 1909 , the bridge was put into commission.

The total length of the bridge reached $42 \mathrm{~m}$, the span lengths being $5 \times 8.0=40.0 \mathrm{~m}$, the roadway being $11.0 \mathrm{~m}$ wide, the both sidewalks $2.45 \mathrm{~m}$, which resulted in the clearance gauge width of $15.90 \mathrm{~m}$. The carrying-deck cambered up to $\sim 15 \mathrm{~cm}$. It was a frame structure with an orthotropic continuous RC carrying-deck rigidly connected with pillars, where each pillar was constructed as a row of $5 \mathrm{RC}$ columns. The columns and piles featured square sections whose side was $40 \mathrm{~cm}$. The pillars were braced by a horizontal bottom cord aided by some cross braces running from the cord to the othotropic plate at the terminal fields. The total price of the bridge amounted to $32000 \mathrm{rb}$.

In comparison with today's EN-1901-2 [10] standard the bridge was able to meet the requirements of the load class for footbridges i.e. the LM4 load model.

\footnotetext{
${ }^{2}$ The majority of monthly issued magazines are accessible on the web site: http://lib.ugent.be/lebetonarme/
} 
In 1984 the city traffic over the bridge was closed, excluding pedestrians and cyclists, however. Fortunately, on 31 December 1987 the bridge was put on the list of Heritage Monuments featuring No A/956, which put paid to numerous disassembling plans. At that time the condition was rather imprecise, which was caused especially by an effect of concrete corrosion resulting from both so-called winter traffic upkeep based on the use of salt solution to prevent icing and also lack of proper deck hydro-isolation [5].

\subsection{Numerical Analyses}

As it has already been said, there was no technical documentation of the bridge, so the method of those days analysis remains still undiscovered. However, there exists an independent protocol of proof tests where the girder bending load capacity was written down as $336 \mathrm{kNm}$.

On the basis of the element sections and reinforcement inventory it was possible to estimate the resistance of elements of the whole structure in general. In Figure 3 the FEM model of the bridge is shown, where the panel of a bridge deck was modelled by shell $2 \mathrm{D}$ elements and the net of beams as well as a pile-column system by bar elements.

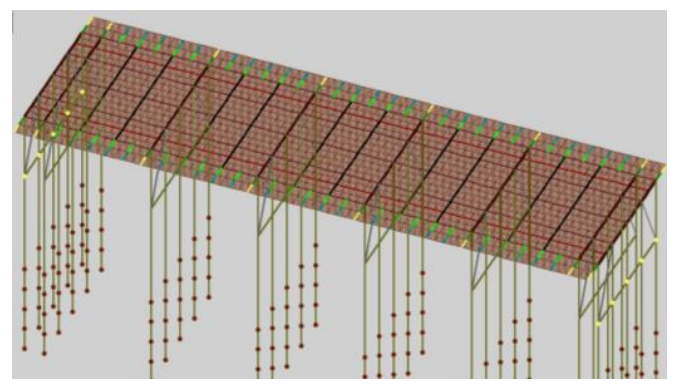

Figure 3. FEM model

The geological upper strata are of alluvial type, which means a very low geotechnical resistance. As a result, the layers with the relevant carrying ability start at $\sim 3 \mathrm{~m}$ under ground level, when piles meet sand layers.

The bridge was numerically investigated in many aspects. The most important one was searching for the bending moment distribution in the carrying-deck, which is featured in Figure 4. This result is aided by next Figure 5, where the bending moments distribution for the terminal girder are very clearly shown in two cases:

- for foot bridge load, according to crowd load LM4 [6],

- when the vehicle of $24 \mathrm{~T}$ as a limit weight is allowable for road traffic.

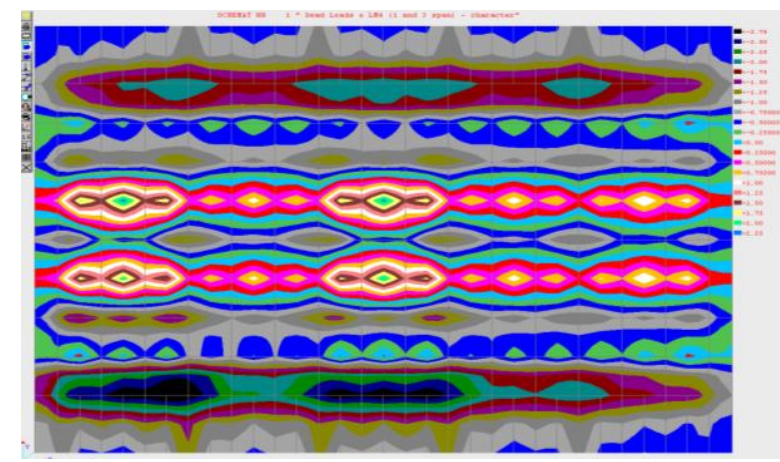

Figure 4. The map of $\mathrm{M}_{\mathrm{y}}$ bending moment distribution in the bridge carrying-deck due to the action of a crowd according to LM4

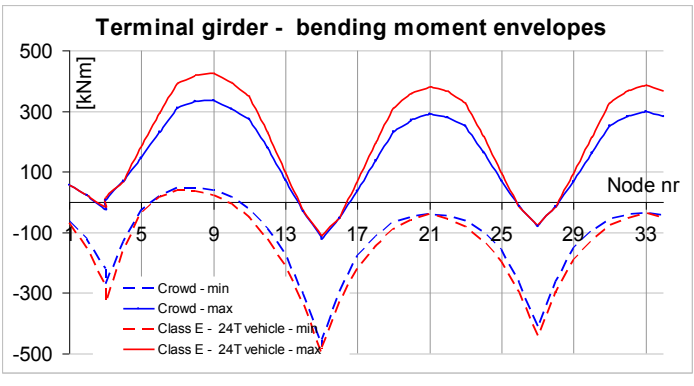

Figure 5. Bending moment distribution at terminal girder; red - crowd load, blue - min class load $\mathrm{E}$, where the max vehicle weight is $24 \mathrm{~T}$

Although the dynamic analysis is redundant here, its findings disclose insufficient lateral stiffens. The first natural bending frequency equal to $v_{1}=3,3624 \mathrm{~Hz}$ is conjugated with the mode shown in Figure 6, where the structure cumber is outward the longitudinal vertical plane. This effect was predictable because all timber type bridges were not laterally rigid enough.

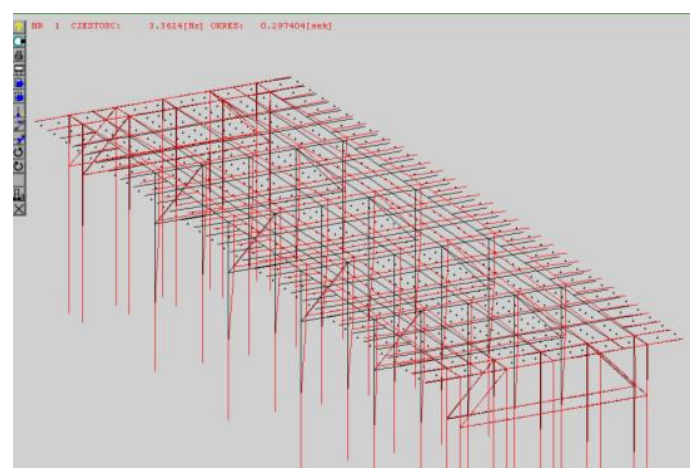

Figure 6. The structure first mode, for $v_{1}=3,3624 \mathrm{~Hz}$

On balance - the bridge, according to bridge standards, was overloaded for its whole service life.

\subsection{Rebuilding}

At the beginning of $21^{\text {st }} \mathrm{c}$. aroused the question how to proceed the bridge restoration. A small group of LUT scientists got engaged in activating the local civil engineering society, both students and municipal authorities, making them acquainted with the historical and technical value of those witnesses to the earlier RC period, and also with the significance of the bridges resulting from their uniqueness for technical heritage, not only locally in Poland but all over the world.

There being two bridges and a highly limited possibility of action, the Old Bridge was decided to be focused on because of its almost central location in the city and the addendum, i.e. a neo-gothic balustrade of extreme interest for architects.

A highly positive atmosphere was created by an avalanche of lectures, conference papers, articles in the technical literature and newspaper interviews. Finally, a happy coincidence with dr eng. Adam Wasilewski of LUT winning the election for the city president post. It was him to decide to commence the bridge reconstruction process. The project in question was neither good nor bad, that is why some advantageous corrections were successfully introduced by the municipal conservator who triggered additional consultations. The reconstruction was started in the spring of 2011 and completed by the end of the same year. 


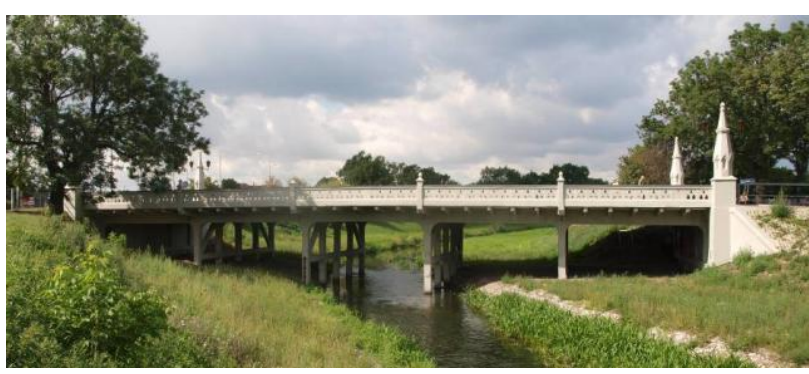

Figure 7. The present side view on the bridge, July 2012

The final result is featured in Figure 7 and Figure 8. It could be said that the Old Bridge like Phoenix from ashes has returned from decay to recover its previous splendid appearance and to decorate the city.

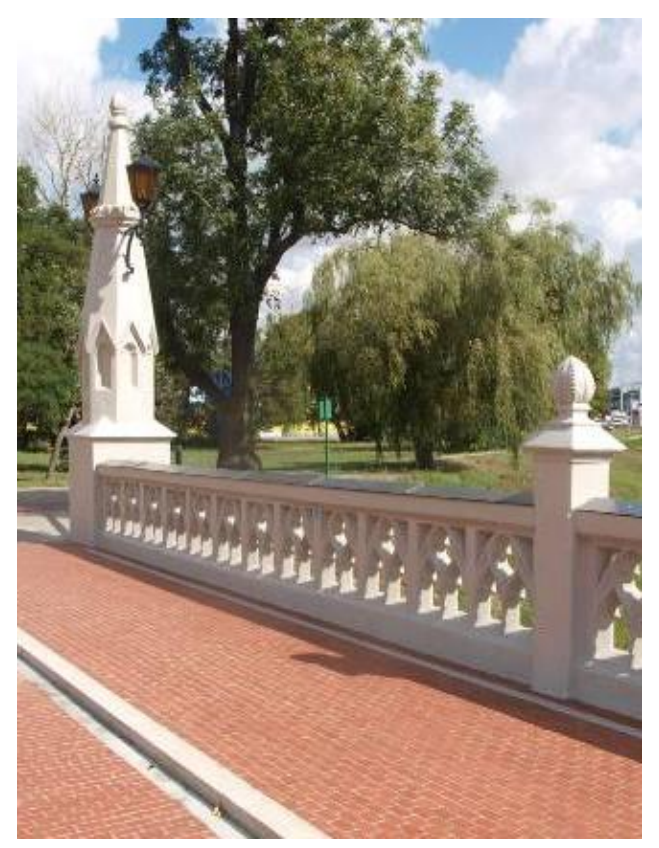

Figure 8. Decorative barrier with terminal columns

By virtue of the Municipal Council decision the bridge was named after Engineer Marian Lutoslawski.

\subsection{Testing Results of 100 Year Old Concrete}

As it is visible in Figure 9 the big concrete blocks were disassembled. Some of them were then taken to the university laboratory where the cores of a nominal diameter of $100 \mathrm{~mm}$ were drilled out to form concrete specimens of the length of $100 \mathrm{~mm}$, the strength value of which is equivalent to the strength value of a $150 \mathrm{~mm}$ cube in compression tests.

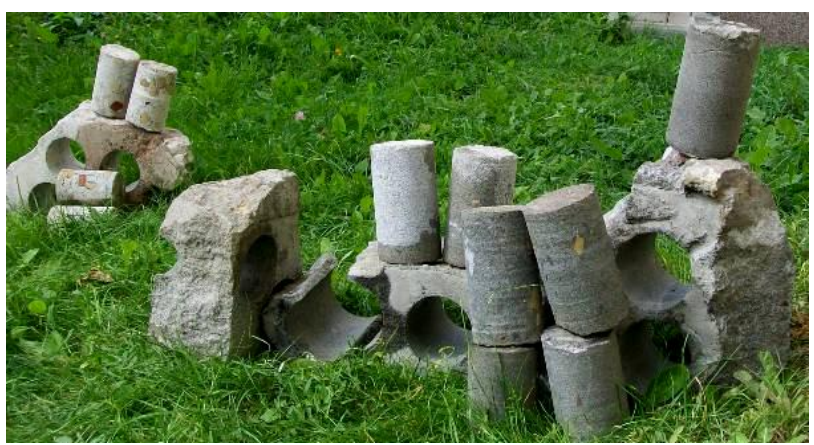

Figure 9. The core samples taken from the over 100 year old concrete blocks
Surprisingly enough not one type of concrete was found but 5 different sorts. The testing of the old historical concrete appeared a fascinating experience. Before the compression tests the concrete samples were examined by means of non destructive methods, a chemical and physical analysis. The Table 1 features the results received in compliance with EN 13791 [12], where the concrete strength was analytically related to the characteristic (5\%) after 28 days cube strength $\mathrm{f}_{\text {ck,cube, }},[11]$.

\begin{tabular}{|c|c|c|c|c|c|}
\hline \multicolumn{7}{|c|}{ Table 1. Results of compression tests } \\
\hline $\mathrm{Nr}$ & $\begin{array}{c}\text { Sort of } \\
\text { concrete }\end{array}$ & $\begin{array}{c}\sigma_{\mathrm{m}} \\
{\left[\mathrm{N} / \mathrm{mm}^{2}\right]}\end{array}$ & $\begin{array}{c}v \\
{[1]}\end{array}$ & $\begin{array}{c}\sigma_{95 \%} \\
{\left[\mathrm{~N} / \mathrm{mm}^{2}\right]}\end{array}$ & $\begin{array}{c}\sigma_{28} \\
{\left[\mathrm{~N} / \mathrm{mm}^{2}\right]}\end{array}$ \\
\hline 1 & $\begin{array}{c}\text { Carrying- } \\
\text { deck }\end{array}$ & 52,62 & 0,12 & 42,53 & 37,36 \\
\hline 2 & Abutment & 39,27 & 0,02 & 37,78 & 33,19 \\
\hline 3 & $\begin{array}{c}\text { Prefabricated } \\
\text { elements }\end{array}$ & 33,30 & 0,11 & 27,19 & 23,88 \\
\hline 5 & $\begin{array}{c}\text { Sand } \\
\text { concrete }\end{array}$ & 35,75 & 0,19 & 24,86 & 21,84 \\
\hline
\end{tabular}

\subsection{The Strengthening that was not Needful}

Already in the bridge renovation project it was calculated that continuous deck beams did not comply with the standards in use now, especially when the shear was considered. As a result by the designer decision some additional shear reinforcement, see Figure 10, was introduced.

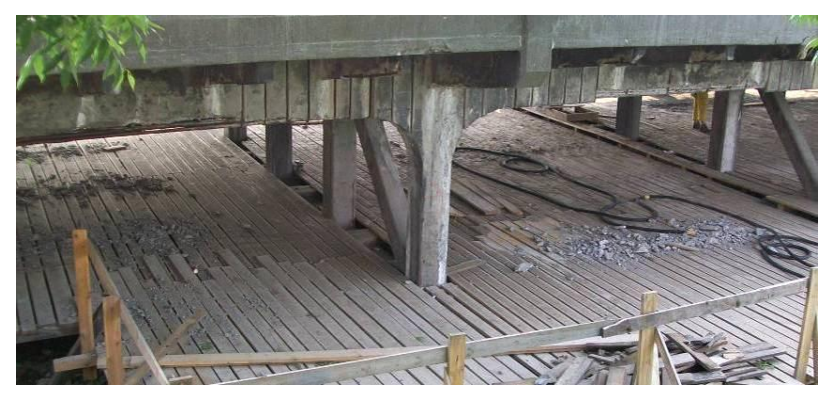

Figure 10. The Strengthening - additional shear reinforcement

However, this decision was strongly criticized by Road and Bridge Chair of LUT and additionally by the municipal monuments conservator who definitely supported the zero option i.e. the variant without any modification of the structure. The reinforcement was not indispensible. In case of beams the shear failure is easy to diagnose through characteristic cracks sloping at ca $45 \mathrm{deg}$ angle. A hundred years of the bridge surviving without any sheer cracks proved no sufficient reason when the computer computed the lack of shear capacity. Nonetheless in a sense the original Hennebique's structure was altered. Fortunately, the stirrups were covered and are not visible.

\section{The Revelation of Hennebique's RC Bridge Concept}


The statement [7]: " the 'patron' would soon be making everything in Béton Armé" is quoted to show how F. Hennebique saw the bridge when the replacement of wooden piles with RC was in question. This sounds crucial and opens up the possibility of following the path leading to Hennebique's RC beam bridge concept. Arc bridges are excluded on account of being in a sense an extension of RC Monier's arc concept. Even though F. Hennebique constructed the prominent Rissorgimento Bridge in Rome, the first one made of RC to attain $100 \mathrm{~m}$ at span, such arcs are omitted.

In Figure 11 the basic constructional elements of a typical wooden beam bridge are shown.

The abutment consists of two practically independent rows of piles (piles change over into columns).

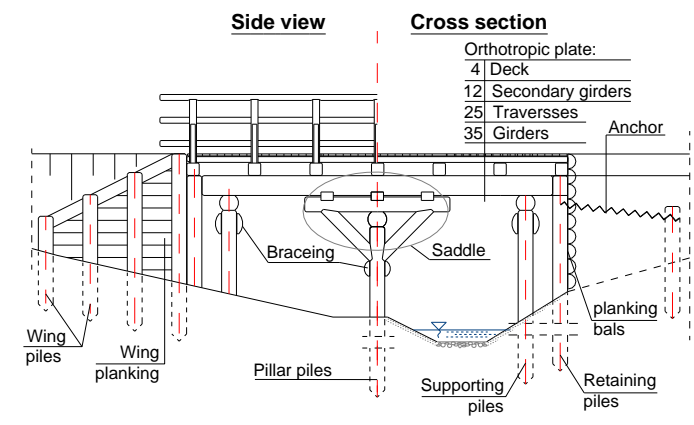

Figure 11. The draft of a wooden bridge

The inside row, supporting piles, forms the supports for the girders of the bridge deck. The second outside row, retaining piles, creates columns on which the retaining wall rests taking the horizontal ground pressure. Piles were also applied as retaining verticals for the wing wall. In case of longer bridges all columns were braced by diagonal and horizontal bars.

The carrying-deck consists of main girders, traverses and two pavement layers constituting the orthotropic panel. But when one "compresses" the elements listed above together, one shall receive the full analogy to Hennebique's RC orthotropic carrying-deck, the deck consisting of longitudinal and cross beams integrated with a RC plate.

During the restoration of the bridge some partial disassembling of the abutments was indispensible to perform, which showed the Hennebique abutment constructed as two separate walls, see Figure 12.

The main structural element for the inside walls were columns filled with a skin plate. The outside wall took a real wall form with a zigzag cross-section in plane which rendered it additionally stiff.

When one looks at the figures mentioned above, one could probably find the advanced similarity between them. Also the columns' bracing looks exactly like the transverse bracing of wooden bridge pillars.

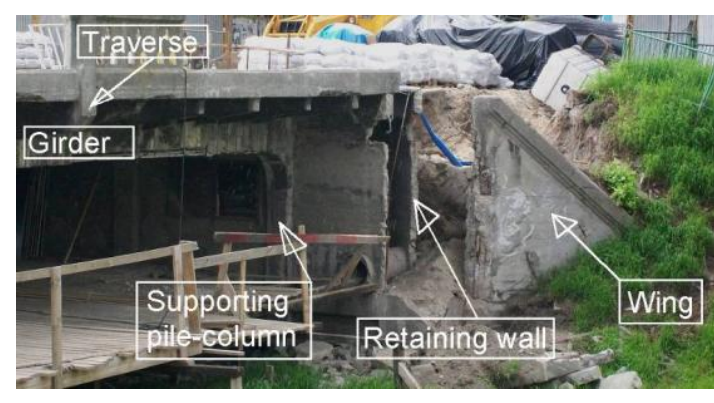

Figure 12. The Hennebique's RC abutment of Old Bridge

\section{Conclusions}

The Hennebique's bridges discussed here could be treated as a totally successful transformation of the verified wooden bridge scheme and technology into the material novel at the time, i.e. RC.

The successful historic bridge restoration described here does not put an end to the problem. There is another Hennebique's bridge in Lublin, Figure 1, also believed to be an unique element of RC engineering culture and history. A great many further efforts are needed to restore it as well and render it an object of beauty once more.

\section{References}

[1] Brocato M., Gulli M., Mazzoli C., The flat arch model in the Church of Saint-Sulpice, IN_BO. Ricerche e progetti per il territorio, la città e l'architettura, 5,2012, p. 290-308.

[2] Cusac P., Agents of change: Hennebique, Mouchel and ferroconcrete in Britain, 1897-1908, Construction History, Vol. 3, 1987.

[3] Delhumeau G., L'Empire Hennebique, Architecture, Mouvement, Continuité, $\mathrm{n}^{\circ} 11,1990$, p. 48-52.

[4] Emperger F., Handbuch für Eisenbetonbau, Verlag von Wilhelm Ernst \& Sohn, Berlin 1911, p. 99.

[5] Karaś S., Gazda L., History and contemporary technical condition of RC bridges made in Hennebique technology in Lublin; Дороги і Мости, випуск 7, UDC 624.21, Kiev, 2007, p. 333-343.

[6] Kierdorf A., Why Hennebique Failed in Germany. Strategies and Obstacles in the Introduction of a New Construction Technology, Proc. of The Third International Congress of Construction History, Cotbus, 2009.

[7] McBeth D. G., Francois Hennebique (1842-1921) - Reinforced concrete pioneer, Proceedings of the Institution of Civil Engineers, 1998, 126, 86-95.

[8] Ragot G., The Hennebique archives: Toward a new corpus for contemporary architectural history, American Archivist, Vol. 59, Spring 1996.

[9] Van de Voorde Stephenie, Hennebique's Journal le Béton Armé. A Close Reading of the Genesis of Concrete Construction in Belgium, Proc. of The Third International Congress of Construction History, Cotbus, 2009

[10] EN 1991-2 Eurocode 1: Actions on structures - Part 2: Traffic loads on bridges; 4.3.5 Load Model 4 (crowd loading).

[11] EN 1992-1-1 Eurocode 2: Design of concrete structures - Part 1-1: General rules and rules for buildings.

[12] EN 13791 Assessment of in-situ compressive strength in structures and precast concrete components. 